DOI: $10.36108 / \mathrm{ssan} / \mathbf{8 8 9 1 . 0 1 . 0 1 3 0}$

\title{
ASPECTS OF THE HUMAN FACTOR IN NATIONAL DEVELOPMENT*
}

\section{P. K. MAKINWA-ADEBUSOYE \\ University of Benin, Benin}

It is a well-known, often repeated fact that Nigeria is potentially a wealthy country, well-endowed in natural and human resources. To realise this potential, there is a need, according to general consensus, to become self-reliant. The most recent appeal for self-reliant economic growth for all African countries came from the Conference of African Ministers of Planning at Addis Ababa in April, 1987. As noticed during this meeting, most traditional international donor countries have reneged on past promises and "it is when Africa (Nigeria included) attempts to stand on its own feet against vicissitudes and adverse challenges that the international community will be ready to come to its assistance". Here at home, the President, both hi his 1986 and '87 budget addresses enumerated economic reconstruction, social justice and self-reliance as the basic goals of the present administration.

In this regard, there is a lot to learn from the Chinese experience where mass mobilization of the country's large population has proved adequate as a partial substitute for capital and has aided the slow but sure movement from poverty to self-sustaining growth. Similarly, Brazil's recent economic achievements have laid to rest the popular, albeit erroneous myth that tropical heat exerts such debilitating effects as to permanently retard economic development. The fault, therefore, is not with our climate or natural resource base but with the wastage of our human resources.

The theme for this year's General Assembly of the Social Science Council of Nigeria presents a unique opportunity for me to dwell, at some length, on two issues which are central to the question of national development and social justice. Education, particularly of the youth $\backslash$, and enhancement of female participation are central to development, whether narrowly or broadly perceived as increased GDP or meeting the basic needs of the people.

The youth represent the starting point for future socio-economic growth. Hence the recognized need to invest in their education and thus build a solid foundation for the future. Realization of expected returns from current massive investment in rural development for increased agricultural production 'hinges, to a large extent, on the degree of enlightenment and literacy of the

\section{-Presidential Address, 1987}




\section{Annals of the Social Science Council of Nigeria}

rural population who are expected to grasp new opportunities; the need for structural change in agriculture calls for literate farmers. As borne out by the discussion during the recent Social Science Council Workshop on small-scale Food Processing and Distribution Industries, women play a central role in food production, processing and distribution. Furthermore, their reproductive role and their role in food preparation within the family have important implications for levels of infant mortality and nutritional intake. The latter consideration, no doubt, influenced the Federal Governments recent concern for female education. While it is true that women's latent resources can be transformed through education into effective human capital, it is important to stress that mass mobilization of female resources will not derive from education alone.

\section{Primary Education: 1960-1987}

The central place of education in the process of economic development is not in doubt. Young citizens need to be educated up to a certain minimum level in the right thought* and skills to boost social and economic development. Neo-classical economic theories suggest that the amount of human capital - mainly education, training and onthe-job experience - will ultimately determine labour productivity. Consequently, low levels of, or complete lack of human capital in terms of education will translate into lower productivity per worker. Besides its other numerous beneficial effects, the importance of education in raising productivity is sufficient reason for our concern about the present state of primary school education. While recognizing that the present crisis in the nation's educational system is not confined to the primary level, it is being examined as the inevitable foundation on which higher education is based.

At independence, in 1960, Nigeria inherited a poor educational legacy from the British colonial administration. There were 15,703 primary schools containing only 2.9 million pupils. Only approximately one out of three children of primary school age was in school. To recover from such a poor start, successive Nigerian governments since independence had allocated a sizeable proportion of the budget for each five-year development plan and the lion's share of annual budgets to the education sector. The importance attached to education is underscored by its prominent inclusion in the 1979 Constitution. According to Section 18 of the 1979 Constitution, the governments of the federation are to provide free primary, secondary, university and adult literacy programmes "as and when practicable". Thus, in the long run, and as stated in the National Policy on Education "government's ultimate objective is to make education free at all levels". To show its commitment the Federal Government introduced the Universal Primary Education Scheme (UPE) at the beginning of the 1976/77 school year and it was to become compulsory in 1979. Within five years of the introduction of the.UPE Scheme, primary school enrolment more than doubled, rising from 6,165,547 in 1975-76 to $12,117,483$ in 1979-80. The enrolment rate-of primary school pupils rose steadily from about 33 per cent in 1960 to 93 per 
cent of children of primary school age (6-11 years) in the 1982/83 school year. But there, the happy story of ever-increasing primary school enrolment ended.

Official statistics indicate that the 1983/84 school year witnessed a dramatic drop in total enrolment and, for the first time in many years, primary school enrolment rate dropped below 90 per cent. It decreased from 93 per cent recorded in the 1982/83 year to 88 per cent in the 1983/84 session. These decreases are directly connected with the country's ailing economy which has resulted in drastic reductions in public spending on education, necessitating the reintroduction of school fees, now euphemistically termed "levies". Recent pronouncements credited to State Commissioners of Education and Governors of some states led to suggestion that there might be more dramatic decreases in primary school enrolment since the 1983/84 school year. The "inability of parents to cope with these levies caused a reduction in, school enrolment.

While enrolment figures continue to decrease it is doubtful whether those in school are receiving high quality education. Answers to the on-going debate on the falling standard of education are necessarily qualified and tentative as various yardsticks are applicable to the measurement of quality. However, there is a consensus of opinion that the whole of Nigeria's educational system is in crisis.

When the UPE Scheme became compulsory in 1979, the Federal Government assumed "full financial responsibility for the scheme in all its various ramifications" ostensibly to free states from the huge capital and recurrent expenditure of the UPE Scheme. However, the Federal Government has since reneged on this promise and demanded that states bear nearly all of the costs of primary education. Events in recent years have clearly shown that the states cannot afford the cost of primary education. The combined effects of shortage of public funds and parents' worsening economic conditions is that many primary schools experience shortage of essential infrastructural and instructional facilities such as classroom space, school furniture, laboratory and science equipment and books. The poor conditions in schools are further exacerbated by the large number of unqualified teachers - 45.46 per cent of primary school teachers during the 1983/84 year were untrained. This has led to the present situation whereby many graduates of primary schools are not functionally literate.

There is an obvious necessity, based on the foregoing analysis, for the Federal Government to relieve impecunious state governments of their present burden and take over total financing of primary education which should also be made compulsory. In fact, at present standards, education up to the Junior Secondary School level should be regarded as the basic minimum education required for development and, as such, should be free and compulsory.

Not so obvious are the following salient points which should inform future educational policies. First, at an annual growth rate of over 3 per cent per annum, efforts to maintain present rates of enrolment of about 90 
per cent of the eligible primary school population is like aiming at a moving target. 90 per cent annual enrolment rates translates into ever-growing increases in actual enrolment figures. This involves more costs in teachers' salaries and provision of necessary instructional materials. Second, because primary school leavers are not equipped with any marketable skills, increasingly large numbers will seek secondary education. Lastly, the new emphasis on vocational/technical education will involve additional costs in salaries of specialized teachers of technical subjects and costs of equipment and laboratories.

In summary, rising enrolment, increasing numbers of teachers, attempts to match quantity with quality and the shift in secondary education to vocational/technical and science subjects mean that the cost per pupil is likely to spiral. Already, there are ample signs to show that there are no short cuts. Ill-equipped classrooms, shortage of physical facilities, and failure to pay teachers' salaries, as and when due, have all contributed to the falling standard of education.

\section{Female Labour Force Participation}

Late last year, the Federal Government announced a Blueprint for Female Education. No doubt, the concern for female education is an attempt to get to grips with one major cause of existing gross under-representation of women in the formal labour sector. The rationale for the new policy derives from neo-classical theories that emphasize sex differences in variables, such as education and training experience, which affect labour productivity and labour supply and thereby labour force participation levels and wages. Yet, the neo-classical perspective is flawed by the underlying assumption that women have equal access to jobs and compete on an equal basis in the labour market. In reality, the labour market is almost rigidly segmented as men and women get cast in different occupational slots. Whereas it is, true that the amount and nature' of the educational attainment of Nigerian women is; a very important factor in their insignificant share of the formal labour market-this does not represent the full explanation. Education and other investment in human capital are at work not in one labour market open to all but in at least two sex-based occupational compartments. Restrictions in occupational choices create a 'crowded' situation in which there is an oversupply of candidates for the so-called women's jobs. This is the case in the nursing profession today. Hence, in the search for the main cause of male/female differences in labour force participation, other factors, besides those in the economic realm, need to be examined. Statistical discrimination, whereby negative stereotypes penalize all women and the intrinsic prejudices in our social mores which are responsible not only for direct discrimination in the labour market, but also for indirect discrimination built into the socialization and educational processes, are important cultural variables which economic theories usually accept as given.

It is precisely the pervasive viewpoint that women's positions in the home and in the society are 'given' that is rightly questioned by other theories 
which insist that it is unrealistic to separate women's position in the labour market, from the entire social system in which women are cast in the subordinate role.

The foregoing discussion is to support the point that government's method of solving the problem of low levels of female participation in the formal labour market does not go far enough. Policies and programmes aimed at facilitating and ensuring greater participation must go beyond special female-oreinted educational programmes. For example, agricultural $£$ extension workers, who tend to overlook rural women due to the culturally accepted, but erroneous belief that women are not bona fide farmers but participate only in harvesting, processing and marketing of farm produce, jeopardize efforts to increase agricultural productivity. The practice ,of limiting most available credit facilities to male farmers and small scale entrepreneurs to the exclusion of most women also impedes economic growth.

The Blue-Print for female education needs to be complemented by a campaign for change in societal attitudes towards women's contributions to national development. There still exists nationwide, a counter-productive tendency to trivialize women's work. The national goal of self-reliant economic growth will be attainable only when we, as a nation, have evolved a system which guarantees equal and full participation of women who represent about half of our human resources.

\section{Conclusion}

In closing, let me reiterate the need for a certain minimum education -up to the Junior Secondary School level - below which the goal of self-sustained economic growth will remain a mirage. In this regard, attention is drawn to falling enrolment and the lack luster performance of our primary schools due mainly to economic recession and resulting decrease in family incomes. The importance of education in all spheres of life and in efforts to increase agricultural productivity and rural development cannot be overemphasized. The Federal Government should match its policy prescriptions with methods of implementation. If, according to existing policy, primary education is free then the Federal Government should provide the money for financing it. At the same time, basic education, that is up to Junior Secondary School level, is a right and a necessary springboard for self-reliant development, and should be free and compulsory.

To reduce and eventually close the male-female gap in educational attainment and enhance female participation in national development, the Federal Government's blueprint of female education is a bold step in the right direction. It needs to be stressed, however, that beyond education, government's intervention is necessary to bring about changes in those cultural attributes which impede female participation, thus depriving the entire nation of their potential contributions in rural areas, and in the formal and informal sectors of the urban labour market. 